Article

\title{
In Vitro Assessment of the Antiviral Activity of Ketotifen, Indomethacin and Naproxen, Alone and in Combination, against SARS-CoV-2
}

\author{
Pantea Kiani ${ }^{1}$, Andrew Scholey ${ }^{2}$ D, Thomas A. Dahl ${ }^{3}$, Lauren McMann ${ }^{3}$, Jacqueline M. Iversen ${ }^{3, *}$ \\ and Joris C. Verster ${ }^{1,2}$ iD \\ 1 Division of Pharmacology, Utrecht Institute for Pharmaceutical Sciences (UIPS), Utrecht University, \\ 3584 CG Utrecht, The Netherlands; p.kiani@uu.nl (P.K.); j.c.verster@uu.nl (J.C.V.) \\ 2 Centre for Human Psychopharmacology, Swinburne University, Melbourne, VIC 3122, Australia; \\ andrew@scholeylab.com \\ 3 Sen-Jam Pharmaceutical, 223 Wall St., \#130, Huntington, NY 11743, USA; tadahl@sen-jam.com (T.A.D.); \\ lmcmann@sen-jam.com (L.M.) \\ * Correspondence: jackie@sen-jam.com
}

check for

updates

Citation: Kiani, P.; Scholey, A.; Dahl, T.A.; McMann, L.; Iversen, J.M.; Verster, J.C. In Vitro Assessment of the Antiviral Activity of Ketotifen, Indomethacin and Naproxen, Alone and in Combination, against SARS-CoV-2. Viruses 2021, 13, 558. https://doi.org/10.3390/v13040558

Academic Editors: Kenneth Lundstrom and Alaa A. A. Aljabali

Received: 5 March 2021

Accepted: 25 March 2021

Published: 26 March 2021

Publisher's Note: MDPI stays neutral with regard to jurisdictional claims in published maps and institutional affiliations.

Copyright: (c) 2021 by the authors. Licensee MDPI, Basel, Switzerland. This article is an open access article distributed under the terms and conditions of the Creative Commons Attribution (CC BY) license (https:/ / creativecommons.org/licenses/by/ $4.0 /)$.

\begin{abstract}
The 2019 coronavirus infectious disease (COVID-19) is caused by infection with the new severe acute respiratory syndrome coronavirus (SARS-CoV-2). Currently, the treatment options for COVID-19 are limited. The purpose of the experiments presented here was to investigate the effectiveness of ketotifen, naproxen and indomethacin, alone or in combination, in reducing SARS$\mathrm{CoV}-2$ replication. In addition, the cytotoxicity of the drugs was evaluated. The findings showed that the combination of ketotifen with indomethacin (SJP-002C) or naproxen both reduce viral yield. Compared to ketotifen alone $\left(60 \%\right.$ inhibition at $\left.\mathrm{EC}_{50}\right)$, an increase in percentage inhibition of SARSCoV-2 to $79 \%, 83 \%$ and $93 \%$ was found when co-administered with 25,50 and $100 \mu \mathrm{M}$ indomethacin, respectively. Compared to ketotifen alone, an increase in percentage inhibition of SARS-CoV-2 to $68 \%, 68 \%$ and $92 \%$ was found when co-administered with 25,50 and $100 \mu \mathrm{M}$ naproxen, respectively. For both drug combinations the observations suggest an additive or synergistic effect, compared to administering the drugs alone. No cytotoxic effects were observed for the administered dosages of ketotifen, naproxen, and indomethacin. Further research is warranted to investigate the efficacy of the combination of ketotifen with indomethacin (SJP-002C) or naproxen in the treatment of SARS-CoV-2 infection in humans.
\end{abstract}

Keywords: antiviral; drug repurposing; SARS-CoV-2; COVID-19; SJP-002C; indomethacin; ketotifen; naproxen; mast cell stabilizer

\section{Introduction}

Coronaviruses are a large family of viruses that cause illness ranging from the common cold to more serious diseases such as Middle East Respiratory Syndrome (MERS) and Severe Acute Respiratory Syndrome (SARS). In December 2019, an outbreak of respiratory disease in China was found to be caused by a novel coronavirus SARS-CoV-2 that causes the disease Coronavirus Infectious Disease of 2019 (COVID-19).

SARS-CoV-2 virus is an enveloped, positive-sense, single-stranded RNA beta-coronavirus [1-6]. The clinical progression of COVID-19 ranges from asymptomatic carriage to fulminant cytokine storm with respiratory failure, multi-organ dysfunction and ultimately death. It has been described that SARS-CoV-2 mediated inflammatory response has three different stages [5] (see Figure 1). Stage I, early infection, is characterized by increased cytokine and chemokine production. Stage I is the incubation period when SARS-CoV-2 multiplies and establishes residence in the host, primarily focusing on the respiratory system. Symptoms reported during Stage I are usually mild and often non-specific, including 
fever, cough, diarrhea, and headache. Stage II of COVID-19 infection, the pulmonary phase, is divided into two distinct parts: pneumonia without hypoxia (Stage IIA) or pneumonia with hypoxia (Stage IIB). During Stage IIB, symptoms worsen and patients will likely require hospitalization and oxygen supplementation. Stage III is the most severe stage, which manifests as an extrapulmonary systemic hyper inflammation syndrome, driven by the cytokine storm. Stage III is characterized by exuberant inflammation resulting from high circulating cytokines such as interleukin (IL)-6 and tumor necrosis factor alpha (TNF- $\alpha)$ [7-12]. These inflammatory mediators are responsible for the multi-organ damage, including acute respiratory distress syndrome (ARDS) and cardiac and renal dysfunction [13-15]. In general, the prognosis and recovery from Stage III are poor.

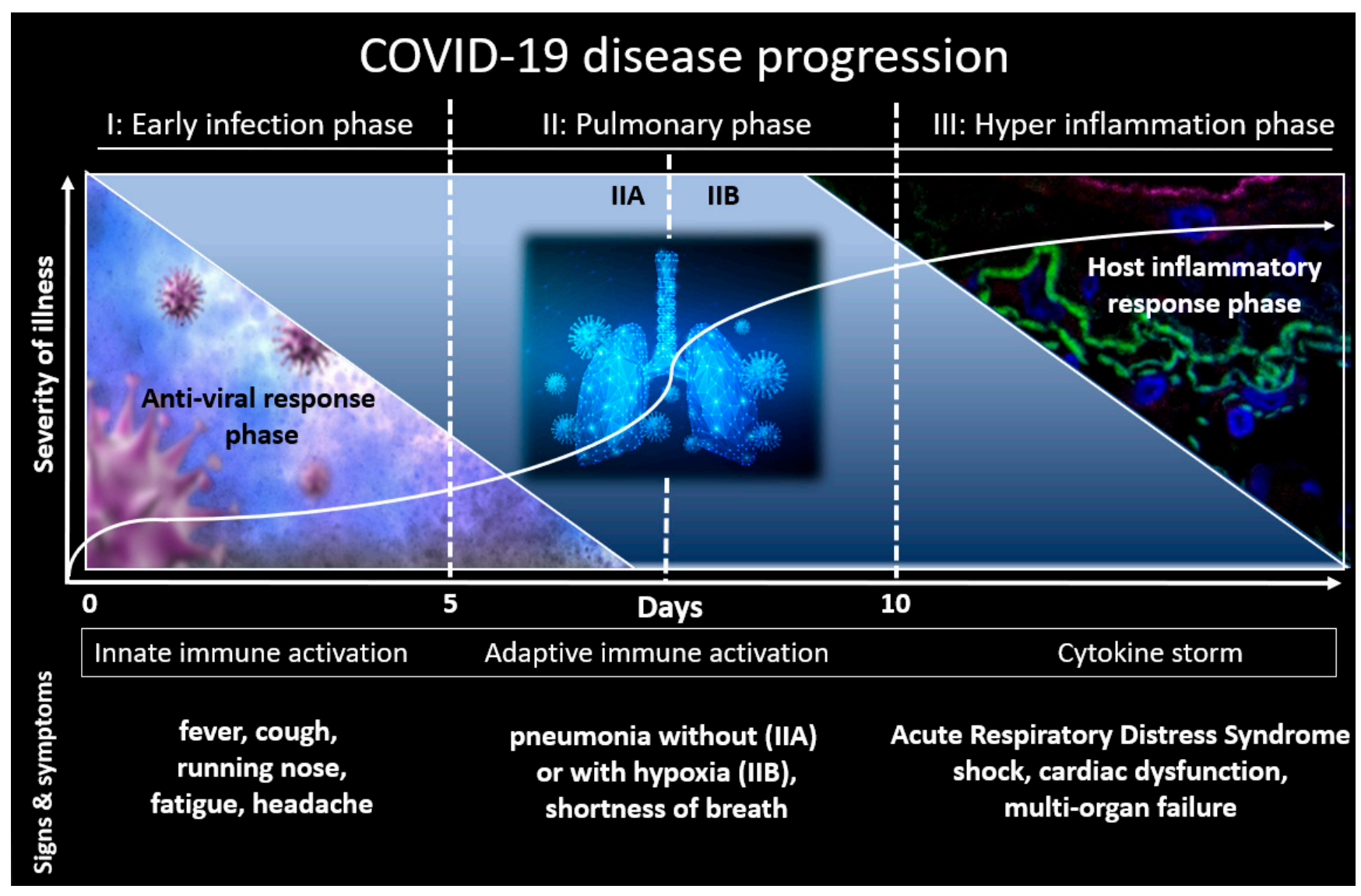

Figure 1. COVID-19 disease progression.

In addition to inhibition of viral replication, blunting this inflammatory response before overt cytokine storm is important to improve outcomes $[7,16,17]$. Although remdesivir and convalescent plasma are used for this purpose, there is a need for adjunct treatments to ameliorate disease burden.

In vitro susceptibility of viruses to an antiviral agent is usually assessed using a quantitative assay to measure virus replication in the presence of increasing concentrations of the product compared to replication in the absence of the product. The half maximal effective concentration is the concentration of product at which virus replication is inhibited by 50 percent $\left(\mathrm{EC}_{50}\right)$. Assays that evaluate antiviral activity include, but are not limited to, virus inactivation assays, plaque reduction assays, cytopathic effect inhibition assays, peripheral blood mononuclear cell (PBMC) assays, and binding and fusion assays [18]. Additionally, compounds must also be evaluated for cellular toxicity. The cytotoxic effect of a compound is usually determined in a cell line of relevance, by calculating the cellular cytotoxicity concentration $\left(\mathrm{CC}_{50}\right)$, i.e., the concentration of the test compound that reduces cell viability by $50 \%$, compared with the cell control value. 
Data of animal models and non-human primate models support that mast cells are strongly activated during SARS-CoV-2 infection, producing damage to the lung tissue, with haemorrhaging visible on the lungs and fluid accumulation in the lungs $[19,20]$. Traditionally, mast cell stabilizers such as ketotifen have been in used in humans for the treatment of allergy and asthma, and these drugs are thought to act by preventing degranulation of mast cells [21-23]. Sen-Jam Pharmaceutical is developing combination therapeutics for the treatment of COVID-19, including a mast cell stabilizer and a non-steroid anti-inflammatory drug. These products are thought to have both antiviral and anti-inflammatory properties, capable of reducing viral replication and the excessive immune response, typically referred to as cytokine storm. In the current study, the combination product ketotifen and indomethacin (SJP-002C) and the combination product ketotifen and naproxen are investigated. It is hypothesized that both combination products can be used early in the treatment of COVID-19 to modify disease progression, and in combination with standard of care. As broad-spectrum anti-inflammatory drugs, reducing both cyclooxygenase and inhibiting mast cell degranulation, together ketotifen and indomethacin can maximally reduce immune mediated inflammation. A further advantage of the combination products is that ketotifen may provide protection against possible indomethacin or naproxen-induced gastrointestinal (GI) injury.

The purpose of the experiments presented here were to investigate the effectiveness of ketotifen, naproxen and indomethacin, alone or in combination, in reducing virus replication. In addition, the cytotoxicity of the drugs was evaluated.

\section{Materials and Methods}

Ketotifen, indomethacin, and naproxen were sourced from Sigma Aldrich and remdesivir from MedChemExpress SARS-CoV-2 hCoV-19/Australia/VIC01/2020 was a gift from Melbourne's Peter Doherty Institute for Infection and Immunity and African Green Monkey Kidney (Vero E6) cells obtained from ATCC (ATCC-CRL1586) (Noble Park North, VIC, Australia).

Virus stocks were expanded via passage in Vero E6 cells in growth media, which comprised Minimal Essential Medium without L-glutamine supplemented with $1 \%(w / v)$ L-glutamine $1.0 \mu \mathrm{g} / \mathrm{mL}$ of TPCK-Trypsin, $0.2 \%$ BSA, $1 \times$ Pen $/$ Strep, and $1 \%$ Insulin Transferrin Selenium (ITS).

African Green Monkey Kidney (Vero E6) cells (ATCC-CRL1586) were sub-cultured to generate cell bank stocks in cell growth medium, which comprised of Minimal Essential Medium (MEM) without L-glutamine supplemented with 10\% $(v / v)$ heat-inactivated Fetal Bovine Serum (FBS) and 1\% $(w / v)$ L-glutamine. Vero E6 cells were passaged for a maximum of 13 passages, after which a new working cell bank stock was retrieved from liquid nitrogen for further use.

\subsection{Study 1. Cytopathic Effect (CPE) Assay}

In Study 1, the cytopathic effects of indomethacin, ketotifen, and naproxen were compared with remdesivir (positive control).

Vero E6 cells were seeded into 96-well plates at $2 \times 10^{4}$ cells/well in $100 \mu \mathrm{L}$ seeding medium (MEM supplemented with 1\% (w/v) L-glutamine, $2 \%$ FBS). Plates were incubated overnight at $37^{\circ} \mathrm{C}, 5 \% \mathrm{CO}_{2}$. Test compounds were prepared fresh on the day of testing, vortexed and visually inspected to confirm complete dissolution.

The positive control compound remdesivir was prepared as a $10 \mathrm{mM}$ stock in dimethyl sulfoxide (DMSO) and stored at $-20^{\circ} \mathrm{C}$. Compound dilutions were prepared on the day of experimentation. A 3 -fold, 8 point, DMSO dilution series of each of the four test compounds was performed initially, ranging $100 \mathrm{mM}$ to $0.045 \mathrm{mM}$. An intermediate dilution series in virus growth medium (MEM supplemented with 1\% $(w / v)$ L-glutamine, $2 \% \mathrm{FBS}, 8 \mu \mathrm{g} / \mathrm{mL}$ Tosyl Phenylalanyl Chloromethyl Ketone (TPCK)-Trypsin was generated ranging $800 \mu \mathrm{M}-$ $0.37 \mu \mathrm{M}$. A $50 \mu \mathrm{L}$ volume from each compound intermediate dilution series was added to 
triplicate wells of the assay plate pre-seeded with Vero E6 cells. The DMSO concentration was maintained at $0.2 \%$ in the assay plate. One assay plate per compound was generated.

Similarly, remdesivir was subjected to an initial DMSO dilution series, intermediate dilution series to reduce the DMSO concentration to $0.2 \%$ in the assay plate. Remdesivir was tested at a starting concentration of $20 \mu \mathrm{M}$.

A $50 \mu \mathrm{L}$ volume of SARS-CoV-2 diluted in virus growth medium to generate a multiplicity of infection (moi) of 0.05 , was added to the assay plates. This moi was previously determined to provide $100 \%$ cytopathic effect (CPE) in 4 days. Virus was added to triplicate rows to assess antiviral activity and virus growth medium without virus was added to triplicate rows to assess cytotoxicity.

The percent cell protection achieved by the positive control (remdesivir) and test articles in virus-infected cells was calculated by the formula of Pauwels et al. [24] as shown below:

Percent cell protection $=([\mathrm{ODt}]$ virus $-[\mathrm{OD}]]$ virus $/[\mathrm{ODc}]$ mock $-[\mathrm{ODc}]$ virus $) \times 100$

where:

[ODt]virus = the optical density measured in a well examining the effect of a given concentration of test article or positive control on virus-infected cells.

$[O D c]$ virus $=$ the optical density measured in a well examining the effect of the negative control on virus-infected cells.

[ODc]mock $=$ the optical density measured in a well examining the effect of the negative control on mock-infected cells.

The $\mathrm{EC}_{50}$ values were calculated from the percent cell protection results by non-linear regression analysis using the Hill (sigmoid Emax) formula:

$$
\mathrm{y}=\operatorname{Min}_{\mathrm{y}}+\left(\operatorname{Max}_{\mathrm{y}}-\operatorname{Min}_{\mathrm{y}}\right) / 1+\left(\mathrm{EC}_{50} / \mathrm{x}\right)^{\mathrm{D}}
$$

where:

$\mathrm{X}=$ test or control article concentration;

$\mathrm{Y}=$ percent cell protection;

Min = minimum;

Max = maximum;

$\mathrm{D}=$ slope coefficient.

\subsection{Study 2. Yield Reduction Assay}

Vero E6 cells were seeded into 96-well plates at $2 \times 10^{4}$ cells/well in $100 \mu \mathrm{L}$ seeding medium (MEM supplemented with 1\% (w/v) L-glutamine, 2\% FBS). Plates were incubated overnight at $37{ }^{\circ} \mathrm{C}, 5 \% \mathrm{CO}_{2}$. Ketotifen, indomethacin and naproxen were prepared as outlined in Section 2.1 above.

For combination studies, compounds were added together in the deep well plate in a 1:1 ratio, then $100 \mu \mathrm{L}$ volume of compound combination was added to cell monolayers. A $200 \mu \mathrm{L}$ volume of virus (B3) was added to plates (moi 0.003).

After $48 \mathrm{~h}$ incubation, virus was harvested at each concentration and diluted 1:10 $(n=1)$ or 1:100 $(n=2)$ in virus growth media. One hundred microliters were added to triplicate wells of 96-well plates containing Vero E6 cells and serially diluted three-fold across the plate for a total of nine different virus concentrations. Six of the wells contained assay media alone (i.e., no virus) and served as controls. Plates were incubated for three days at $37^{\circ} \mathrm{C}$ in a humidified $5 \% \mathrm{CO}_{2}$ atmosphere during which time the $\mathrm{CPE}$ was allowed to develop. Cell monolayers were then observed microscopically with visual scoring of virus-induced CPE used as an endpoint. The TCID 50 of the virus suspension was determined using the method of Reed-Muench [25]. The virus yield was expressed as a percentage with respect to virus growth when no drug was added, for each concentration. 


\subsection{Study 3. Cytotoxicity Assay}

The cytotoxic effects of indomethacin, ketotifen, and naproxen on Vero E6 cells was tested over a 4 day or $48 \mathrm{~h}$ period to mimic either the antiviral assay or the yield reduction assay. Drugs were tested at the same concentration as those used in Sections 2.1 and 2.2. Viable cells were determined by staining with MTT or crystal violet. A $100 \mu \mathrm{L}$ volume of a $3 \mathrm{mg} / \mathrm{mL}$ solution of MTT was added to plates and incubated for $2 \mathrm{~h}$ at $37^{\circ} \mathrm{C}$ in a $5 \% \mathrm{CO}_{2}$ incubator. Wells were aspirated to dryness and formazan crystals solubilized by the addition of $200 \mu \mathrm{L} \mathrm{100 \%} \mathrm{2-Propanol} \mathrm{at} \mathrm{room} \mathrm{temperature} \mathrm{for} 30 \mathrm{~min}$. Absorbance was measured at 540-650 $\mathrm{nm}$ on a plate reader. Media were removed from cells stained with crystal violet and washed once with PBS. A $40 \mu \mathrm{L}$ volume of $0.25 \%$ crystal violet $/ 20 \%$ methanol stain was added to each well and incubated for $30 \mathrm{~min}$ at room temperature. Crystal violet stain was aspirated, monolayers washed 3-5 times with PBS and the stain solubilized with the addition of $100 \mu \mathrm{L} 1 \%$ sodium dodecyl sulfate (SDS). After $30 \mathrm{~min}$ at room temperature, absorbance was measured at $540-650 \mathrm{~nm}$ on a plate reader. The $50 \%$ cytotoxic concentration $\left(\mathrm{CC}_{50}\right)$ was defined as the concentration of the test compound that reduces the absorbance of the mock infected cells by $50 \%$ of the control value. The $\mathrm{CC}_{50}$ value was calculated as follows:

$$
\mathrm{CC}_{50}=[\mathrm{ODt}] \text { mock } /[\mathrm{ODc}] \text { mock }
$$

\section{Results}

\subsection{Study 1. Cytopathic Effect (CPE) Assay}

Results of Study 1 are shown in Table 1. None of the treatments exhibited antiviral activity in the 4 days CPE assay.

Table 1. $\mathrm{EC}_{50}$ and $\mathrm{CC}_{50}$ data from the $\mathrm{CPE}$ assay.

\begin{tabular}{ccc}
\hline Compound & $\mathrm{EC}_{\mathbf{5 0}}(\mu \mathrm{M})$ & $\mathrm{CC}_{\mathbf{5 0}}(\boldsymbol{\mu M})$ \\
\hline Ketotifen & $>138.6$ & 138.6 \\
Naproxen & $>400$ & $>400$ \\
Indomethacin & $>400$ & $>400$ \\
Remdesivir & 2.9 & $\mathrm{NT}$ \\
\hline
\end{tabular}

\subsection{Study 2. Yield Reduction Assay}

The compounds were then tested in a Yield Reduction Assay (YRA) under reduced rounds of virus replication $(48 \mathrm{~h}$ ) to see if any antiviral activity was observed. The results for ketotifen and naproxen are summarized in Table 2 and Figure 2. Ketotifen alone inhibited SARS-CoV-2 and exhibited an $\mathrm{EC}_{50}$ of $48.9 \mu \mathrm{M}$. Naproxen alone did not inhibit SARS-CoV-2 and exhibited an $\mathrm{EC}_{50}$ of $>100 \mu \mathrm{M}$.

Table 2. $\mathrm{EC}_{50}$ and percentage inhibition of SARS-CoV-2: $50 \mu \mathrm{M}$ ketotifen $\mathrm{EC}_{50}$ in combination with naproxen.

\begin{tabular}{cccccccc}
\hline & \multicolumn{7}{c}{ Concentration Naproxen $(\boldsymbol{\mu M})$} \\
\hline Treatment & $\mathbf{E C}_{\mathbf{5 0}}$ & $\mathbf{1 0 0}$ & $\mathbf{5 0}$ & $\mathbf{2 5}$ & $\mathbf{1 2 . 5}$ & $\mathbf{6 . 2 5}$ & $\mathbf{3 1 2 5}$ \\
\hline Ketotifen & 48.9 & - & 68 & 0 & 0 & 0 & 0 \\
Naproxen & $>100$ & 0 & 0 & 0 & 21 & 0 & - \\
Naproxen EC $_{50}+$ & $<6.25$ & 92 & 68 & 68 & 75 & 60 & - \\
$50 \mu$ M ketotifen & & & &
\end{tabular}

$\mathrm{EC}_{50}$ is the effective concentration of product, i.e., the concentration at which virus infection is inhibited by 50 percent. 


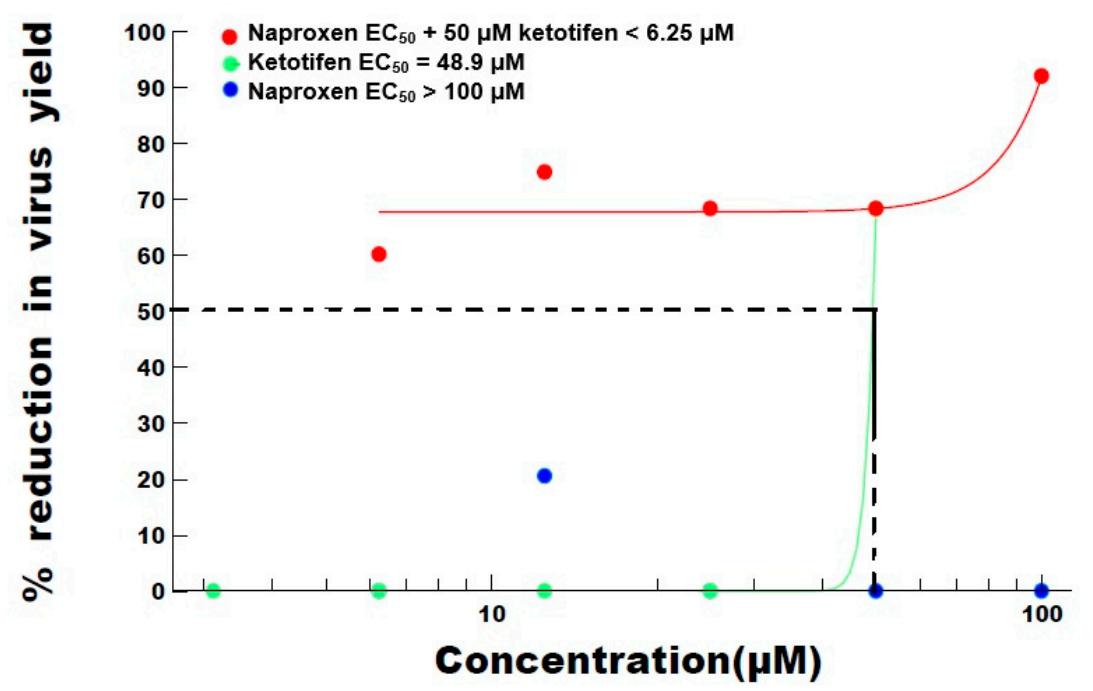

Figure 2. Dose-response curves for naproxen and ketotifen, alone and in combination. $\mathrm{EC}_{50}$ is the effective concentration of product, i.e., the concentration at which virus infection is inhibited by 50 percent.

When ketotifen was added at a single concentration, naproxen's ability to reduce virus yield was enhanced. The $\mathrm{EC}_{50}$ of naproxen was reduced to $<6 \mu \mathrm{M}$, equating to $\sim 17$-fold greater effect in the presence of ketotifen. The dose-response curves are shown in Figure 2. These data indicate an additive or synergistic effect (See Figure 2).

The results for ketotifen and indomethacin are summarized in Tables 3 and 4. Table 3 reveals that, compared to ketotifen alone $\left(60 \%\right.$ inhibition at $\left.\mathrm{EC}_{50}\right)$, an increase in percentage inhibition of SARS-CoV-2 to $79 \%, 83 \%$ and $93 \%$ was observed when co-administered with 25,50 and $100 \mu \mathrm{M}$ indomethacin, respectively, indicating an additive or synergistic effect.

Table 3. $\mathrm{EC}_{50}$ and percentage inhibition of SARS-CoV-2: $50 \mu \mathrm{M}$ ketotifen in combination with indomethacin.

\begin{tabular}{ccccccc}
\hline & \multicolumn{5}{c}{ Concentration Ketotifen $(\boldsymbol{\mu M})$} \\
\hline Treatment & $\mathbf{E C}_{\mathbf{5 0}}$ & $\mathbf{5 0}$ & $\mathbf{2 5}$ & $\mathbf{1 2 . 5}$ & $\mathbf{6 . 2 5}$ & $\mathbf{3 1 2 5}$ \\
\hline Ketotifen & 47.1 & 60 & 0 & 0 & 0 & 0 \\
Ketotifen $+100 \mu \mathrm{M}$ indomethacin & 48.1 & 94 & 0 & 0 & 37 & 0 \\
Ketotifen $+50 \mu \mathrm{M}$ indomethacin & 46.5 & 97 & 0 & 0 & 0 & 37 \\
Ketotifen $+25 \mu \mathrm{M}$ indomethacin & 42.2 & 90 & 0 & 0 & 0 & 0 \\
\hline
\end{tabular}

$\mathrm{EC}_{50}$ is the effective concentration of product, i.e., the concentration at which virus infection is inhibited by 50 percent.

Table 4. $\mathrm{EC}_{50}$ and percentage inhibition of SARS-CoV-2: $100 \mu \mathrm{M}$ indomethacin in combination with ketotifen.

\begin{tabular}{ccccccc}
\hline & \multicolumn{5}{c}{ Concentration Indomethacin $(\mu \mathbf{M})$} \\
\hline Treatment & $\mathbf{E C}_{\mathbf{5 0}}$ & $\mathbf{1 0 0}$ & $\mathbf{5 0}$ & $\mathbf{2 5}$ & $\mathbf{1 2 . 5}$ & $\mathbf{6 . 2 5}$ \\
\hline Indomethacin & 100.1 & 50 & 0 & 0 & - & - \\
Indomethacin $+50 \mu \mathrm{M}$ ketotifen & $<6.25$ & 93 & 83 & 79 & 75 & 60 \\
Indomethacin $+25 \mu \mathrm{M}$ ketotifen & $>100$ & 0 & 0 & 0 & - & - \\
Indomethacin $+12.5 \mu \mathrm{M}$ ketotifen & $>100$ & 0 & 0 & 0 & - & - \\
Indomethacin $+6.25 \mu \mathrm{M}$ ketotifen & $>100$ & 37 & 0 & 0 & - & - \\
Indomethacin $+3.125 \mu \mathrm{M}$ ketotifen & $>100$ & 0 & 37 & 0 & - & -
\end{tabular}

$\mathrm{EC}_{50}$ is the effective concentration of product, i.e., the concentration at which virus infection is inhibited by 50 percent. - = not assessed.

Indomethacin alone inhibited SARS-CoV-2 and exhibited an $\mathrm{EC}_{50}$ of $100.1 \mu \mathrm{M}$ (see Table 4). Indomethacin did not reach an $\mathrm{EC}_{50}$ in the presence of $50 \mu \mathrm{M}$ ketotifen, although $60 \%$ inhibition was observed at $6.25 \mu \mathrm{M}$ indicating that an $\mathrm{EC}_{50}$ would probably be reached 
at $\sim 3 \mu \mathrm{M}$ had the dilution series had covered a lower range. These in vitro data indicate that a lower dose of indomethacin is required to inhibit virus growth in the presence of $50 \mu \mathrm{M}$ of ketotifen, indicating an additive or synergistic effect. Indomethacin did not reach an $\mathrm{EC}_{50}$ in the presence of $25 \mu \mathrm{M}, 12.5,6.25$ or $3.1 \mu \mathrm{M}$ ketotifen.

When ketotifen was added at a single concentration, indomethacin's ability to reduce virus yield was enhanced. The $\mathrm{EC}_{50}$ of indomethacin was reduced to $<6 \mu \mathrm{M}$, equating to $\sim 13$-fold greater effect in the presence of ketotifen. Figure 3 shows the dose-response curves for indomethacin and ketotifen, alone and in combination. The dose-response curves suggest an additive or synergistic antiviral effect against SARS-CoV-2 when ketotifen and indomethacin are administered in combination.

- Indomethacin $\mathrm{EC}_{50}+50 \mu \mathrm{M}$ ketotifen $<6.25 \mu \mathrm{M}$

Ketotifen $\mathrm{EC}_{50}=36.8 \mu \mathrm{M}$

- Indomethacin $\mathrm{EC}_{50}=78 \mu \mathrm{M}$

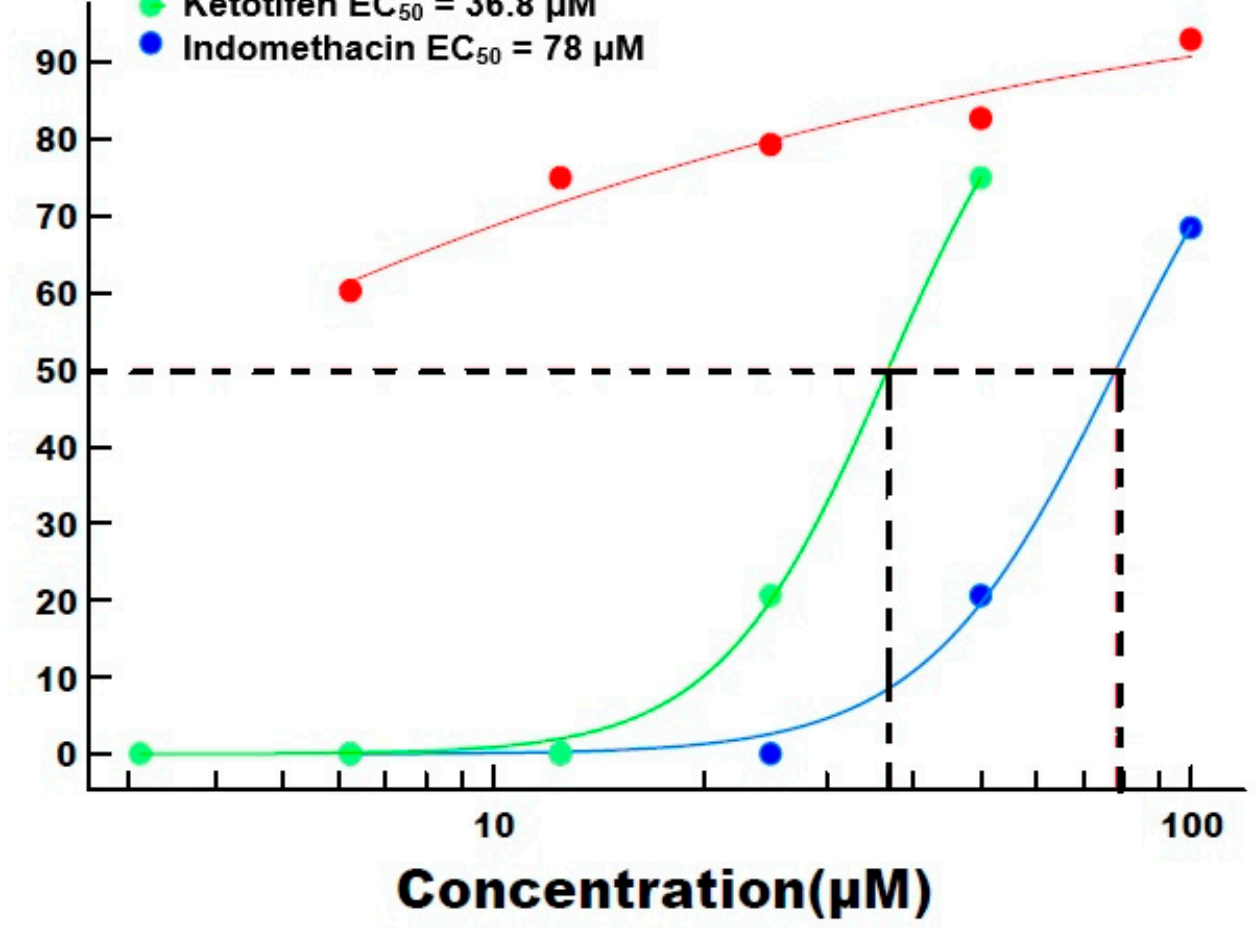

Figure 3. Dose-response curves for indomethacin and ketotifen, alone and in combination.

\subsection{Study 3. Cytotoxicity Assay}

The results of the cytotoxicity assessments are summarized in Table 5 . The 50\% cytotoxic concentration $\left(\mathrm{CC}_{50}\right)$ was defined as the compound concentration required for the reduced cell viability by $50 \%$. No cytotoxicity was observed for indomethacin, naproxen and ketotifen at the concentrations tested.

Table 5. Percentage viability at different concentrations of ketotifen, naproxen, and indomethacin.

\begin{tabular}{ccccccccccc}
\hline Concentration $(\boldsymbol{\mu M})$ & $\mathbf{1 0 0}$ & $\mathbf{5 0}$ & $\mathbf{2 5}$ & $\mathbf{1 2 . 5}$ & $\mathbf{6 . 2 5}$ & $\mathbf{3 . 1 3}$ & $\mathbf{1 . 5 6}$ & $\mathbf{0 . 7 8}$ & $\mathbf{0 . 3 9}$ & $\mathbf{0 . 2 0}$ \\
\hline Indomethacin $(\%)$ & 143 & 143 & 125 & 124 & 124 & 117 & 111 & 106 & 98 & - \\
Naproxen $(\%)$ & 107 & 108 & 107 & 107 & 106 & 112 & 96 & 112 & 108 & - \\
Ketotifen $(\%)$ & - & 86 & 104 & 122 & 125 & 121 & 109 & 101 & 103 & 110 \\
\hline
\end{tabular}

\section{Discussion}

The current findings show that both the combination products ketotifen and indomethacin (SJP-002C) and ketotifen and naproxen reduce viral yield. Compared to ketotifen alone $\left(60 \%\right.$ inhibition at $\left.\mathrm{EC}_{50}\right)$, an increase in percentage inhibition of SARSCoV-2 to $90 \%, 97 \%$ and $94 \%$ was found when co-administered with 25,50 and $100 \mu \mathrm{M}$ 
indomethacin, respectively, indicating an additive or synergistic effect. The $\mathrm{EC}_{50}$ of indomethacin was reduced to $<6 \mu \mathrm{M}$, equating to $\sim 13$-fold greater effect in the presence of ketotifen. Compared to ketotifen alone $\left(60 \%\right.$ inhibition at $\left.\mathrm{EC}_{50}\right)$, an increase in percentage inhibition of SARS-CoV-2 to $68 \%, 68 \%$ and $92 \%$ was found when co-administered with 25,50 and $100 \mu \mathrm{M}$ naproxen, respectively. This also indicates an additive or synergistic effect, but the reduction in viral yield was smaller than observed with SJP-002C. Finally, no cytotoxic effects were observed for the concentrations of ketotifen, indomethacin, and naproxen tested.

Scientific evidence supports the observed efficacy of ketotifen in combination with indomethacin (SJP-002C) or naproxen in reducing viral yield. Both naproxen [26,27] and indomethacin [26] have shown-either by computer simulation or in vitro studies- to inhibit viral nucleoprotein involved in viral replication of SARS-CoV-2. Amici et al. [28] described indomethacin's antiviral activity against SARS-CoV in vitro in Vero E6 cells and in human epithelial lung cells. [29-32]. In humans, naproxen has been added to oseltamivir and clarithromycin for the treatment of influenza, which resulted in a significantly reduced 30-day mortality, intensive care unit stay, and hospitalization in general [33]. Indomethacin showed efficacy of improved arterial oxygenation in critically ill patients with severe bacterial pneumonia [34] and in adults with respiratory distress syndrome [35]. In relation to the aim of the combination products to reduce excessive immune response, both indomethacin and naproxen have shown to reduce interleukin (IL)- 6 in the plasma and synovial fluids of rheumatoid arthritis patients [36], and in another study indomethacin reduced inflammation in Alzheimer patients [37]. These findings suggest that both naproxen and indomethacin may be effective in counteracting the cytokine storm associated with SARS CoV-2 infection [38-40].

Ketotifen is approved and marketed in Canada, Europe and Asia for chronic urticaria and childhood asthma for over 20 years, with an excellent safety profile. Mast cells have been implicated in the pathogenesis of viral infections, such as human immunodeficiency virus (HIV)-1, dengue virus, cytomegalovirus, and bovine respiratory syncytial virus [41]. Mast cells can intensify immunological injury through the production of mediators, including tryptase, TNF- $\alpha$, IL-6, IL-1, and chemokine (C-C motif) ligand 3 (CCL3). Animal studies have shown that ketotifen can reduce excessive inflammation (cytokine storm), and ketotifen has been shown to reduce end organ damage and mortality in mice infected with H5N1 type Influenza A [42]. Ketotifen has been shown in mice infected with $\mathrm{H} 5 \mathrm{~N} 1$ influenza viral to dramatically reduce lung damage and mortality, even when the antiviral, oseltamivir, was dosed sub-optimally (ketotifen and oseltamivir 100\% survival vs. oseltamivir alone 65\%) [43]. Another study found that ketotifen reduced vasoactive products and vascular leakage (i.e., an IgG mediated immune response to Dengue virus) in mice [19]. Finally, research also showed that ketotifen can exert a protective effect against NSAID induced GI injury [44,45]. Taken together, these findings support that ketotifen has the potential to reduce excessive inflammation and cytokine storm associated with SARS-CoV-2 infection.

Recent research published as preprint also supports our findings with regard to the efficacy of naproxen and indomethacin in reducing SARS-CoV-2 viral yield. For example, Terrier et al. [46] found that naproxen inhibited viral yield in Vero E6 cells and protected bronchial epithelia against SARS-CoV-2 induced-damage. Building upon the work by Amici et al. [28], Xu et al. [47] conducted antiviral SARS-CoV-2 testing in green monkey kidney Vero E6 cells and found that indomethacin had a direct and potent antiviral activity against SARS CoV-2, without cytotoxicity. In contrast, aspirin, the comparator drug in this study, did not show a significant antiviral effect.

Although the mechanisms underlying the antiviral activity of the combination products ketotifen and indomethacin (SJP-002C) and ketotifen and naproxen against coronavirus infection require further investigation, the results shown herein are promising and warrant further investigation. Future research should confirm our findings in animal models. In addition, future research should confirm whether this observation will modify disease 
progression in humans, and if ketotifen in combination with indomethacin or naproxen will reduce cytokine storm and subsequent organ damage and mortality rates associated with COVID-19 disease.

\section{Conclusions}

The current findings show that the combination of ketotifen with indomethacin (SJP002C) or naproxen both significantly reduces viral yield. Compared to ketotifen alone, the combination with indomethacin or naproxen has an additive or synergistic effect. No cytotoxic effects were observed for concentrations of ketotifen, naproxen, and indomethacin tested.

Author Contributions: Conceptualization, T.A.D. and J.M.I.; methodology, T.A.D. and J.M.I.; formal analysis, J.C.V.; interpretation of data, P.K., J.C.V., A.S., T.A.D., L.M. and J.M.I.; writing-original draft preparation, P.K. and J.C.V.; writing-review and editing, P.K., J.C.V., A.S., T.A.D., L.M. and J.M.I.; funding acquisition, J.M.I. All authors have read and agreed to the published version of the manuscript.

Funding: This study was funded by Sen-Jam Pharmaceutical and conducted by 360biolabs.

Institutional Review Board Statement: Not applicable.

Informed Consent Statement: Not applicable.

Data Availability Statement: The data are available from the corresponding author upon reasonable request.

Conflicts of Interest: Over the past 36 months, A.S. has held research grants from Abbott Nutrition, Arla Foods, Bayer, BioRevive, DuPont, Fonterra, Kemin Foods, Nestlé, Nutricia-Danone, Verdure Sciences. He has acted as a consultant/expert advisor to Arepa Nootroptics, Bayer, Coca-Cola, Danone, Naturex, Nestlé, Pfizer, Sanofi, Sen-Jam Pharmaceutical, and has received travel/hospitality/speaker fees from Bayer, Sanofi, and Verdure Sciences. Over the past 36 months, J.C.V. has held grants from Janssen and Sequential Medicine, and acted as a consultant/expert advisor to More Labs, Red Bull, Sen-Jam Pharmaceutical, Toast!, Tomo, and ZBiotics. T.A.D. is partner and Head of Product Development and Regulatory Affairs of Sen-Jam Pharmaceutical. J.M.I. is founder and Head of Clinical Development of Sen-Jam Pharmaceutical. L.M. was intern at Sen-Jam Pharmaceutical when the study was conducted. P.K. has nothing to declare. This independent study was conducted by 360biolabs, without involvement of the authors and the funder. The funder was involved in the design of the study, interpretation of data, writing of the manuscript, and in the decision to publish the results.

\section{References}

1. Zumla, A.; Chan, J.; Azhar, A.; Hui, D.; Yuen, Y. Coronaviruses-drug discovery and therapeutic options. Nature Rev. 2016, 15, 327-347. [CrossRef]

2. Pal, M.; Berhanu, G.; Desalegn, C.; Kandi, V. Severe acute respiratory syndrome coronavirus-2 (SARS-CoV-2): An update. Cureus 2020, 12, e7423. [CrossRef] [PubMed]

3. Ksiazek, T.; Erdman, D.; Goldsmith, C.; Zaki, S.; Peret, T.; Emery, S.; Tong, S.; Urbani, C.; Comer, J.; Lim, W.; et al. A novel coronavirus associated with severe acute respiratory syndrome. N. Engl. J. Med. 2003, 348, 1953-1966. [CrossRef]

4. ECDC Technical Report: Interim Guidance for Environmental Cleaning in Non-Healthcare Facilities Exposed to SARS-CoV-2; European Center for Disease Prevention and Control: Solna, Sweden, 2020.

5. Paules, C.; Marston, H.; Fauci, A. Coronavirus Infections-More Than Just the Common Cold. JAMA 2020, 323, 707-708, [CrossRef]

6. V'kovski, P.; Kratzel, A.; Steiner, S.; Stalder, H.; Thiel, V. Coronavirus biology and replication: Implications for SARS-CoV-2. Nat. Rev. Microbiol. 2020. [CrossRef]

7. Marinella, M. Indomethacin and resveratrol as potential treatment adjuncts for SARS-CoV-2/COVID-19. Int. J. Clin. Pract. 2020, 74, e13535. [CrossRef]

8. Guo, Y.R.; Cao, Q.D.; Hong, Z.S.; Tan, Y.; Chen, S.; Jin, H.; Tan, K.; Wang, D.; Yan, Y. The origin, transmission and clinical therapies on coronavirus disease 2019 (COVID-19) outbreak-an update on the status. Military Med. Res. 2020, 7, 1-10. [CrossRef] [PubMed]

9. Del Valle, D.M.; Kim-Schulze, S.; Huang, H.H.; Beckmann, N.; Nirenberg, S.; Wang, B.; Lavin, Y.; Swartz, T.; Madduri, D.; Stock, A.; et al. An inflammatory cytokine signature predicts COVID-19 severity and survival. Nat. Med. 2020, 26, 1636-1643. [CrossRef] [PubMed] 
10. Dauby, N.; Bottieau, E. The unfinished story of hydroxychloroquine in COVID-19: The right anti-inflammatory dose at the right moment? Int. J. Infect. Dis 2021, 103, 1-2. [CrossRef]

11. Tanacan, A.; Yazihan, N.; Erol, S.; Anuk, A.; Yetiskin, F.; Biriken, D.; Ozgu-Erdinc, A.; Keskin, H.; Tekin, O.; Sahin, D. The impact of COVID-19 infection on the cytokine profile of pregnant women: A prospective case-control study. Cytokine 2021, 140, 155431. [CrossRef]

12. Karki, R.; Karki, R.; Sharma, B.; Tuladhar, S.; Williams, E.; Zalduondo, L.; Samir, P.; Zheng, M.; Sundaram, B.; Banoth, B.; et al Synergism of TNF-a and IFN-g Triggers Inflammatory Cell Death, Tissue Damage, and Mortality in SARSCoV-2 Infection and Cytokine Shock Syndromes. Cell 2021, 184, 149-168. [CrossRef] [PubMed]

13. Hojyo, S.; Hojyo, S.; Uchida, M.; Tanaka, K.; Hasebe, R.; Tanaka, Y.; Murakami, M.; Hirano, T. How COVID-19 induces cytokine storm with high mortality. Inflamm. Regen. 2020, 40, 37. [CrossRef]

14. Mustafa, M.; Abdelmoneim, A.; Mahmoud, E.; Makhawi, A. Cytokine storm in COVID-19 patients, its impact on organs and potential treatment by QTY code-designed detergent-free chemokine receptors. Mediators Inflam. 2020, 2020, 8198963. [CrossRef] [PubMed]

15. Abdulkhaleq, L.A.; Assi, M.A.; Abdullah, R.; Zamri-Saad, M.; Taufiq-Yap, Y.H.; Hezmee, M.N.M. The crucial roles of inflammatory mediators in inflammation: A review. Vet. World 2020, 11, 627-635. [CrossRef] [PubMed]

16. McEvoy, N.; McElvaney, O.; Carroll, T.; Murphy, M.; Dunlea, D.; Choileain, O.; Clarke, J.; O'Connor, E.; Hogan, G.; Ryan, D.; et al. Characterization of the inflammatory response to severe COVID-19 illness. Am. J. Respir. Crit. Care Med. 2020, $202,812-821$.

17. Li, A.; Garcia-Bengochea, Y.; Stechel, R.; Azari, B. Management of COVID-19 myopericarditis with reversal of cardiac dysfunction after blunting of cytokine storm: A case report. Eur. Heart J. Case Rep. 2020, 4, 1-6. [CrossRef]

18. Food and Drug Administration (FDA). Guidance for Industry. Antiviral Product Development_Conducting and Submitting Virology Studies to the Agency; U.S. Department of Health and Human Services, FDA, Center for Drug Evaluation and Research (CDER): Silver Spring, MA, USA, 2006.

19. St John, A.L.; Rathore, A.P.S.; Raghavan, B.; Ng, M.L.; Abraham, S.N. Contributions of mast cells and vasoactive products, leukotrienes and chymase, to dengue virus-induced vascular leakage. eLife 2013, 2, e00481. [CrossRef] [PubMed]

20. Munoz-Fontela, C. Animal models for COVID-19. Nature 2020, 586, 509-515. [CrossRef]

21. Disodium cromoglycate. Lancet 1972, 2, 1299.

22. Theoharides, T.C.; Sieghart, W.; Greengard, P.; Douglas, W.W. Antiallergic drug cromolyn may inhibit histamine secretion by regulating phosphorylation of a mast cell protein. Science 1980, 207, 80-82. [CrossRef]

23. McClean, S.P.; Arreaza, E.E.; Lett-Brown, M.A.; Grant, J.A. Refractory cholinergic urticaria successfully treated with ketotifen. J. Allergy Clin. Immunol. 1989, 83, 738-741. [CrossRef]

24. Pauwels, R.; Balzarini, J.; Baba, M.; Snoeck, R.; Schols, D.; Herdewijn, P.; Desmyter, J.; De Clercq, E. Rapid and automated tetrazoli $\mu \mathrm{M}$-based colorimetric assay for the detection of anti-HIV compounds. J. Virol. Methods 1988, 20, 309-321. [CrossRef]

25. Reed, L.J.; Muench, H. A simple method of estimating fifty percent endpoints. Am. J. Hyg. 1938, $27,493-497$.

26. Lejal, N.; Tarus, B.; Bouguyon, E.; Chenavas, S.; Bertho, N.; Delmas, B.; Ruigrok, R.W.H.; Di Primo, C.; Slama-Schwok, A. structure-based discovery of the novel antiviral properties of naproxen against the nucleoprotein of influenza A virus. Antimicrob. Agents Chemother. 2013, 57, 2231-2241. [CrossRef] [PubMed]

27. Zheng, W.; Fan, W.; Zhang, S.; Jiao, P.; Shang, Y.; Cui, L.; Mahesutihan, M.; Li, J.; Wang, D.; Fu Gao, G.; et al. Naproxen exhibits broad anti-influenza virus activity in mice by impeding viral nucleoprotein nuclear export. Cell Rep. 2019, 27, 1875-1885. [CrossRef] [PubMed]

28. Amici, C.; Di Caro, A.; Ciucci, A.; Chiappa, L.; Castilletti, C.; Martella, V.; Decaro, N.; Buonavoglia, C.; Capobianchi, M.R.; Santoro, M.G. Indomethacin has a potent antiviral activity against SARS coronavirus. Antivir Ther. 2006, 11, 1021-1030.

29. Gomeni, R.; Xu, T.; Gao, X.; Bressolle-Gomeni, F. Model based approach for estimating the dosage regimen of indomethacin a potential antiviral treatment of patients infected with SARS CoV-2. J. Pharmacokin. Pharmacodyn. 2020, 47, 189-198. [CrossRef]

30. Terracciano, R.; Preianò, M.; Fregola, A.; Pelaia, C.; Montalcini, T.; Savino, R. Mapping the SARS-CoV-2-host protein-protein interactome by affinity purification mass spectrometry and proximity-dependent biotin labeling: A rational and straightforward route to discover host-directed anti-SARS-CoV-2 therapeutics. Int. J. Mol. Sci. 2021, 22, 532. [CrossRef]

31. Mostafa, A.; Kandeil, A.; Elshaier, Y.; Kutkat, O.; Moatasim, Y.; Rashad, A.; Shehata, M.; Gomaa, M.; Mahrous, N.; Mahmoud, S.; et al. FDA-Approved drugs with potent In vitro antiviral activity against Severe Acute Respiratory Syndrome Coronavirus 2. Pharmaceuticals 2020, 13, 443. [CrossRef]

32. Baradaran, H.; Hamishehkar, H.; Rezaee, H. NSAIDs and COVID-19: A new challenging area. Pharm. Sci. 2020, 26, S49-S51. [CrossRef]

33. Hung, I.F.N.; To, K.K.W.; Chan, J.F.W.; Cheng, V.C.C.; Liu, K.S.H.; Tam, A.; Chan, T.-C.; Zhang, A.J.; Li, P.; Wong, T.-L.; et al. Efficacy of clarithromycin-naproxen-oseltamivir combination in the treatment of patients hospitalized for influenza A (H3N2) infection: An open-label randomized, controlled, phase IIb/III trial. Chest 2017, 151, 1069-1080. [CrossRef]

34. Hanly, P.J.; Roberts, D.; Dobson, K.; Light, R.B. Effects of indomethacin on arterial oxygenation in critically ill patients with severe distress syndrome. Lancet 1987, 1, 351-354. [CrossRef]

35. Steinberg, S.M.; Rodriguez, J.L.; Bitzer, L.G.; Rhee, J.W.; Kelley, K.A.; Flint, L.M. Indomethacin treatment of human adult respiratory distress syndrome. Circ. Shock 1990, 30, 375-384. 
36. Sacerdote, P.; Carrabba, M.; Galante, A.; Pisati, R.; Manfredi, B.; Panerai, A.E. Plasma and synovial fluid interleukin-1, interleukin-6 and substance $\mathrm{P}$ concentrations in rheumatoid arthritis patients: Effect of the nonsteroidal anti-inflammatory drugs indomethacin, diclofenac and naproxen. Inflamm. Res. 1995, 44, 486-490. [CrossRef]

37. Bour, A.M.; Westendorp, R.G.; Laterveer, J.C.; Bollen, E.L.; Remarque, E.J. Interaction of indomethacin with cytokine production in whole blood. Potential mechanism for a brain-protective effect. Exp. Gerontol. 2000, 35, 1017-1024. [CrossRef]

38. Wu, R.; Wang, L.; Kuo, H.; Shannar, A.; Peter, R.; Chou, P.; Li, S.; Hudlikar, R.; Liu, X.; Liu, Z.; et al. An update on current therapeutic drugs treating COVID-19. Curr. Pharmacol. Rep. 2020, 6, 56-70. [CrossRef] [PubMed]

39. Al-Horani, R.; Kar, S. Potential anti-SARS-CoV-2 therapeutics that target the post-entry stages of the viral life cycle: A comprehensive review. Viruses 2020, 12, 1092. [CrossRef]

40. Robb, C.; Goepp, M.; Rossi, A.; Yao, C. Non-steroidal anti-inflammatory drugs, prostaglandins, and COVID-19. Br. J. Pharmacol. 2020, 177, 4899-4920. [CrossRef]

41. Dilly, S.; Fotso, A.; Lejal, N.; Zedda, G.; Chebbo, M.; Rahman, F.; Companys, S.; Bertrand, H.; Vidic, J.; Noiray, M.; et al. From Naproxen Repurposing to Naproxen Analogues and Their Antiviral Activity against Influenza A Virus. J. Med. Chem. 2018, 61, 7202-7217. [CrossRef] [PubMed]

42. Enkirch, T.; Sauber, S.; Anderson, D.E.; Gan, E.S.; Kenanov, D.; Maurer-Stroh, S.; von Messling, V. Identification and in vivo efficacy assessment of approved orally bioavailable human host protein-targeting drugs with broad anti-influenza A activity. Front Immunol. 2019, 10, 1097. [CrossRef]

43. Hu, Y.; Jin, Y.; Han, D.; Zhang, G.; Cao, S.; Xie, J.; Xue, J.; Li, Y.; Meng, D.; Fan, X.; et al. Mast cell-induced lung injury in mice infected with H5N1 influenza virus. J. Virol. 2012, 86, 3347-3356. [CrossRef] [PubMed]

44. Eliakim, R.; Karmeli, F.; Rachmilewitz, D. Ketotifen-old drug, new indication: Reduction of gastric mucosal injury. Scand J. Gastroenterol. 1993, 28, 202-204. [CrossRef] [PubMed]

45. Narendranathan, M.; Chitra, P.; Kurien, M.; Philip, J. Ketotifen in prevention of indomethacin-induced gastropathy. Indian J. Gastroenterol. 1999, 18, 76-77. [PubMed]

46. Terrier, O.; Dilly, S.; Pizzorno, A.; Henri, J.; Berenbaum, F.; Lina, B.; Fève, B.; Adnet, F.; Sabbah, M.; Rosa-Calatrava, M.; et al. Broad-spectrum antiviral activity of naproxen: From influenza A to SARS-CoV-2 coronavirus. BioRxiv 2020. [CrossRef]

47. Xu, T.; Gao, X.; Wu, Z.; Selinger, D.W.; Zhou, Z. Indomethacin has a potent antiviral activity against SARS CoV-2 in vitro and canine coronavirus in vivo. BioRxiv 2020. [CrossRef] 